Східносвропейський національний університет імені Лесі Українки, кафедра аналітичної економіки та природокористування,

м. Луцьк, ORCID: 0000-0001-7156-643X e-mail: novosad_ox@ukr.net

https://doi.org/10.29038/2411-4014-2020-01-165-172

\title{
НАПРЯМИ ВПРОВАДЖЕННЯ ІННОВАЦІЙНИХ ЗАХОДІВ НА ГАЗОРОЗПОДІЛЬНИХ ПІДПРИЕМСТВАХ ЗАХІДНОГО РЕГІОНУ
}

Анотація. Стаття присвячена аналізу стану газорозподільних підприємств України та необхідності реалізації інноваційних заходів на вказаних підприємствах. Окреслено фактори впливу внутрішньої та зовнішньої дії на функціонування вітчизняних газорозподільних підприємств в напрямі інноваційноінвестиційних зрушень: констатовано, що організаційно-економічна система управління інноваційноінвестиційною діяльністю знаходиться на етапі занепаду та стагнації усієї газотранспортної системи України на всіх рівнях. Виходячи 3 кризового стану газорозподільних підприємств Західного регіону, нами запропоновано впроваджувати ряд інноваційних заходів на мікро, макро та мезорівнях, системах діяльності підприємств. Розроблені теоретичні положення та практичні рекомендації, які включають концепцію діючих інновацій, дуальності інноваційно-інвестиційного капіталу, гнучкості тарифу розподілу газу. Результативність запропонованих нами заходів дозволить імплементувати організаційно-управлінські, технологічні, фінансові, кадрові інновації в діяльності газорозподільних підприємств 3 метою подолання сформованих негативних тенденцій, пов'язаних з входженням їх у стадію занепаду та зміною вектору їх розвитку з орієнтацією на інноваційне впровадження.

Ключові слова: інноваційність, газорозподільні підприємства, організаційно-економічна система, інноваційно-інвестиційна діяльність, дієві інновації, дуальність інноваційно-інвестиційного капіталу, мікроекономічний рівень, макроекономічний рівень, мезоекономічний рівень.

Новосад Оксана, аспирант,

Восточноевропейський национальный университет имени Леси Украинки, кафедра аналитической економики и природопользования, г. Луцк

\section{НАПРАВЛЕНИЯ ВНЕДРЕНИЯ ИННОВАЦИОННЫХ МЕРОПРИЯТИЙ ГАЗОРАСПРЕДЕЛИТЕЛЬНЫХ ПРЕДПРИЯТИЙ ЗАПАДНОГО РЕГИОНА}

Аннотация. Статья посвящена анализу состояния газораспределительных предприятий Украины и необходимости реализации инновационных мероприятий на указанных предприятиях. Определены факторы влияния внутреннего и внешнего воздействия на функционирование отечественных газораспределительных предприятий в направлении инновационно-инвестиционных сдвигов: констатировано, что организационноэкономическая система управления инновационно-инвестиционной деятельностью находится на этапе упадка и стагнации всей газотранспортной системы Украины на всех уровнях. Исходя из кризисного состояния газораспределительных предприятий Западного региона, нами предложено внедрять ряд инновационных мероприятий на микро, макро и мезоуровне, системах деятельности предприятий. Разработаны теоретические положения и практические рекомендации, которые включают концепцию действующих инноваций, дуальности инновационно-инвестиционного капитала, гибкости тарифа распределения газа. Результативность предложенных мероприятий позволит имплементировать организационно-управленческие, технологические, финансовые, кадровые инновации в деятельности газораспределительных предприятий с целью преодоления сложившихся негативных тенденций, связанных с вхождением их в стадию упадка и изменением вектора их развития с ориентацией на инновационное внедрение.

Ключевые слова: инновационность, газораспределительные предприятия, организационноэкономическая система, инновационно-инвестиционная деятельность, действенные инновации, дуальность 
инновационно-инвестиционного капитала, микроэкономический уровень, макроэкономический уровень, мезоэкономических уровень.

\section{Novosad Oksana, \\ Postgraduate, Lesya Ukrainka Eastern European National University, Department of Analytical Economics and Nature Management, \\ Lutsk}

\section{AREAS OF IMPLEMENTATION OF INNOVATION MEASURES ON THE GAS DISTRIBUTION ENTERPRISES OF THE WESTERN REGION}

Summary. The article is devoted to the analysis of the state of gas distribution companies in the western region of Ukraine and the need to implement innovative measures at these companies, since the organizational system of regional gas pipelines is characterized by significant static, conservative, the absence of separate innovative units, and there is a weakened focus of traditional units on the implementation of separate functions related to innovation and investment. The purpose of the article is to investigate innovative policy measures and ways of their implementation at gas distribution companies in Western Ukraine.

The preconditions of forming an effective mechanism for managing innovation and investment activity at gas distribution companies are the theoretical provisions and practical recommendations we have proposed for: 1) existing innovations (innovative business processes); 2) the dualities of private investment capital; 3) flexibility of gas distribution tariff.

The concept of existing innovations involves the widespread use of innovations that cover the entire range of business processes of the enterprise, the priority of which is the improvement of activities in order to choose a vector of orientation for consumers of gas services, and which are aimed at achieving the synergistic effect of the enterprise due to the impact of increasing the efficiency of all its functional units.

The duality of innovation-investment capital at gas-distributing enterprises implies the creation of a complex of both internal (at the enterprise level) and external conditions for attracting such capital in order to solve the problems of innovative development by partial (spot, selective) privatization of existing gas-distributing capacities within the existing enterprises, which require major overhaul, modernization, technical re-equipment, as well as the creation of new logistic and distribution facilities.

Practical implementation of the approach on the unification of distribution tariffs makes it possible to form a mechanism for the distribution of the total tariff revenue received by gas distribution companies or the gas transmission system operator between the entities in proportion to the volume of services provided or to individual components of these services, or on other bases that do not contravene the current legislation.

The effectiveness of measures we proposed will allow us to implement organizational-managerial, technological, financial, personnel innovations in the activities of gas distribution companies in order to overcome the negative trends associated with their entry into the stage of decline and change their development vector with a focus on innovation.

Key words: innovation, gas distribution enterprises, organizational and economic system, innovation and investment activity, effective innovations, duality of innovation and investment capital, microeconomic level, macroeconomic level, mesoeconomic level.

Постановка наукової проблеми та їі значення. Інноваційність, як рушійна сила будь-якої підприємницької структури, без сумніву фінансово доступна великим фірмам, які є локомотивами економічного розвитку. Так, величезні транснаціональні корпорації в умовах міждержавного суперництва постійно удосконалюють інноваційні розробки технологічних, організаційних та збутових параметрів своєї діяльності.

3 огляду на панування мережевих підприємницьких систем, інноваційність спроможна себе проявити і на газорозподільних підприємствах регіону.

Підсумовуючи ефективність діючої організаційно-економічної системи управління інноваційноінвестиційної діяльності газорозподільних підприємств, слід зробити оцінку наскільки $є$ традиційною організаційно-економічна система управління підприємством, яка запроваджується через методи та форми господарської діяльності та реалізує інноваційний розвиток.

Аналіз досліджень цієї проблеми. Теоретичні підходи до різностороннього дослідження інноваційних заходів, як невід'ємних складових успішного функціонування ГРП України окреслено в працях таких дослідників, як М. Басовим, М. Сорокою, В. Купчаком, К. Павловим, В. Петренком, 
С. Кіселем. Методичні підходи до реалізації або способів запровадження інноваційних шляхів розвитку газорозподільних підприємств досліджено іншою плеядою науковців: Н. Лінчевською, О. Дзьобою, 3. Осінчуком, Д. Якимовим, О. Павловою, М. Коротьою.

Однак, обраний вектор дослідження в не достатній мірі визначає пріоритетність та вимірність теоретико-методичного базису, що і послужило підставою для запропонованого нижче сценарію вирішення зазначеної проблеми.

Мета і завдання дослідження. Метою статті $€$ - дослідження заходів інноваційної політики та шляхи їх реалізації на газорозподільних підприємствах Західної України.

Встановлена мета потребувала реалізації ряду завдань:

- оцінити наявну організаційно-економічну систему, газорозподільних підприємств в напрямі готовності сприйняття інноваційних заходів;

- здійснити огляд інституційного середовища газорозподільної сфери;

- змоделювати концепцію інноваційної політики на ГРП;

- підсумувати ефективність теоретико-практичних напрацювань та економічного ефекту від запропонованих заходів в ретроспективній стратегії росту ГРП.

\section{Виклад основного матеріалу й обгрунтування отриманих результатів дослідження.}

Можна стверджувати, що під дією технологічних, науково-технічних, економічних, соціальнополітичних, екологічних, демографічних, організаційно-правових та інших факторів впливу неефективно запроваджувались основні тенденції зростання ринку, аналіз сильних і слабких сторін функціонування суб'єкта господарювання, ринкових загроз та можливостей, що підтримують чи ускладнюють інвестиційно-інноваційну діяльність, вибір та оцінку ефективних варіантів інноваційного розвитку. Результатами цього виявились процеси переходу до етапу стагнації та занепаду вітчизняних газорозподільних підприємств.

За основними напрямами розвитку газорозподільних підприємств, можна виокремити такі види їх діяльності: науково-технічні, виробничо-господарські, збутові. Враховуючи матеріально-технічне забезпечення, інноваційно-інвестиційну діяльність і організаційно-технологічну політику, слід зауважити що саме організаційно-технологічна політика розвивалася впродовж певного періоду загалом неефективно, зокрема у частині запровадження стратегій, оскільки газорозподільні підприємства були майже позбавлені наданих їм повноважень та відповідних ресурсних продуктів.

Сьогодні існуючі газорозподільні підприємства $є$ досить обмежені у визначенні пріоритетів свого існування, оскільки тут збережене централізоване управління та його вагомий вплив зі сторони НАК «Нафтогаз України», Міністерства енергетики та вугільної промисловості України, ПАТ «Укртрансгаз», НКРЕКП. Саме тут необхідно наголосити, що організаційна система регіональних газопроводів характеризується значною статичністю, консервативністю, відсутністю окремих інноваційних підрозділів, а також існує послаблена орієнтація традиційних підрозділів на впровадження окремо виділених функцій, які пов'язані з інноваційно-інвестиційною діяльністю. Отже, в умовах економічної та політичної криз і зростання нестабільності чинників зовнішнього середовища, доцільність реформування організаційних структур управління діючих газорозподільних підприємств обумовлюється зокрема потребами їх адаптації до сприйняття та активного використання типових організаційно-економічних інструментів забезпечення інноваційного розвитку у стані політичної та економічної криз і зростаючої нестабільності чинників зовнішнього середовища [1].

Вивчення обов'язків стимулювання та заохочення інноваційних процесів, а також інструментів ïх вдосконалення на існуючих газорозподільних підприємствах, показало, що вони, грунтуються зокрема на традиційних системах щодо морального та матеріального стимулювання (допомога на оздоровлення, заробітна плата, подяки та трудові відзнаки, квартальне та річне преміювання тощо). Щодо ефективності діяльності будь-якої структури, то вона $\epsilon$ значно залежною саме від обгрунтованості зростання і точності використання його інформаційного потенціалу, який має бути спрямований на підтримку протягом тривалого проміжку часу належного стану конкурентоспроможності, це можливо удосконалити шляхом інноваційності його системи управління.

Варто зазначити, що першою з базових умов ефективного розвитку підсистеми інформаційного забезпечення інноваційно-інвестиційної діяльності виступає залучення сучасних інформаційних 
технологій, а також спроможність підсистеми до адаптації та легкої гнучкості у поставлених управлінських задачах за мінімальних витрат.

На вторинному етапі інноваційного розвитку необхідно здійснювати двостороннє узгодження роботи підрозділів (інженерно-конструкторського відділу, виробничо-технічного відділу матеріально-технічного постачання), котрі разом приймають участь у проекті.

На кінцевому етапі інвестування варто здійснювати нагляд проектів за термінами робіт, змістом та контролем втілення бюджетів інноваційно-інвестиційних проектів, розробку рекомендацій для прийняття управлінських рішень, розгляд відхилень, а також їх впливу на інвестиційний інтерес підприємства.

Ще одна важлива складова ефективності функціонування інноваційної діяльності є своєчасність надходження інформаційних ресурсів та достовірність джерел. Саме ці фактори формують якість управлінських рішень та їх дієвість у визнанні проблем інноваційного піднесення господарюючих суб'єктів, а це свідчить, що постає проблема відкриття релевантних та надійних зародків інформації, які здатні сприяти результативному розвитку вітчизняних компаній та підприємств в умовах раптовості та високої прогнозованості чинників їх виробничо-комерційної діяльності. Таким чином, доводиться відзначити присутність певних проблем, пов'язаних саме із недосконалістю та застарілістю існуючих систем обробки, забезпеченням якості та достовірності наявної інформації, нагромадженням i передачі інформації, неквапністю впровадження сучасних інформаційних технологій на газорозподільних підприємствах, гальмуючою реакцією на зміни в інформаційному просторі [2].

Виходячи 3 вищесказаного, слід констатувати низьку інноваційну привабливість газорозподільних підприємств в результаті впливу чинників внутрішньої та зовнішньої дії. Домінуючі чинники слід групувати за мікро, мезо та макрорівнями. Зокрема, елементами мікроекономічного впливу пропонуємо вважати чинники рівня газорозподільного підприємства, які чинять пряму або дотичну дію на направленість інноваційного розвитку формуючи натуральні, організаційні, соціальні, фінансові, кадрові, збутові та інформаційні інструменти. Водночас, мезоекономічний рівень охоплює систематизовані критерії організаційно-адміністративного, інституційного, інвестиційного та поляризаційного походження.

Відтак, макроекономічний рівень реалізації інноваційної активності поєднується, насамперед із формуванням та втіленням державної та регіональної політики, інституційним вдосконаленням інновацій, ефективністю реалізації методів та інструментів впливу.

Радикальні організаційно-інноваційні зміни одночасно мають включати і мікроекономічний рівень, таким чином розвиваючи належне інноваційне середовище, безпосередньо на підприємствах, а також виходячи із пріоритетів стратегічного розвитку, сучасного їх стану, існуючих загроз та ризиків, які безпосередньо пов'язані із мінливістю зовнішнього середовища. Управління такими ефективними змінами на газорозподільних підприємствах потребує вирішення ряду важливих питань, першочерговими з яких є: формування сучасної бази теоретико-методичного обгрунтування системних інноваційно-інвестиційних заходів з урахуванням екстернальних та синергетичних форм, формування системи управління інноваційним розвитком з чинним інструментарієм управління інноваційно-інвестиційними процесами; організаційно-інноваційне реформування цієї тарифної політики; заміна заходів до підтримки приватного капіталу на основі концепції дифузії інноваційного ланцюга.

Дослідженнями було визнано, що зниження рівня використання виробничого потенціалу газорозподільних підприємств та різка зміна його якісних характеристик було спричинено недосконалістю організаційно-економічних та нормативно-правових способів регулювання їхньої діяльності. Але найбільшою проблемою сьогодні постає дефіцит інвестиційних ресурсів, які необхідні для відновлення та модернізації ГТС на інноваційній основі, спричинений як відсутністю особистих коштів, так і складністю мобілізації позичкових і залучених коштів, а також іноземних інвестицій [3].

Складність залучення інноваційно-інвестиційного капіталу в об'єкти газотранспортної та газорозподільної інфраструктури обумовлена дефіцитом у державному та обласному бюджетах необхідних коштів, а залучення приватного капіталу обмежується відсутністю дієвих та надійних механізмів, котрі б забезпечували його ефективне використання та дозволяли гарантовано 
отримувати необхідну норму прибутку на інвестований капітал. 3 іншого боку, в силу особливостей регіональних газорозподільних мереж, інвестиційні проекти, які пов'язані з реконструкцією та модернізацією виробничих об’єктів, характеризуються тривалим періодом окупності та потребують значних інвестицій.

Саме в таких умовах великий вплив має мінімізація потреб в інвестиційних джерелах, це означає максимально безпечно визначити інвестиційну пріоритетність, виокремлених аспектів: 1) забезпечення надійності газопостачання; 2) максимальне зниження виробничих та позавиробничих витрат; 3) енергозбереження; 4) приведення у відповідність наявних виробничих потужностей до фактичних потреб. Значними перешкодами для залучення приватного інноваційно-інвестиційного капіталу є також законодавчо закріплений майновий статус газорозподільних підприємств України, виробничі об'єкти яких належать до загальнодержавної власності та $є$ частково приватизованими [4], а також ризиків пов'язаних із створенням конкуруючих маршрутів та монополізмом постачальника газу і наявність значних зовнішніх ризиків, найсуттєвішими з яких, на наш погляд, є політичні та фінансові ризики. Так, приватизація ГТС та газових сховищ України, на думку Європейської комісії, вплинула б на зниження корупційної складової [5].

Позитивні і негативні сторони цього підходу варто оцінити у порівнянні із потенційними запасними варіантами майбутнього розвитку ГТС, а саме: 1) збереження існуючого статус-кво, тобто ГТС перебуває у державній власності [6] та управлінні в межах існуючої компанії «Укртрансгаз»; 2) створення дво- чи тристороннього консорціуму; 3) часткова приватизація окремих об'єктів ГРП із збереженням державного контролю та управління за регіональними та газорозподільними підприємствами загалом.

При даних умовах найбільш надійним видається варіант включення приватного інвестиційного капіталу методом часткової приватизації окремих об'єктів ГРП із збереженням державного нагляду та керування за діяльністю ГТС в цілому на основі використання певної концепції вибіркової дифузії особистого інвестиційного капіталу. Запровадження цього підходу потребує внесення змін до діючого законодавства України, а саме до Закону України «Про трубопровідний транспорт» в частині присвоєння дозволу потенційним інвесторам на приватизацію окремих елементів ГТС, які $€$ цілісними дискретними предметами інвестування, або ж передачу у довготривалу оренду таких об'єктів. В даному випадку з'являється можливість включення приватного інноваційноінвестиційного капіталу для відновлення та покращення саме тих об'єктів ГТС, яким це найбільше необхідно у даний період. Ця система може запроваджуватись і при спорудженні нових об'єктів ГТС, які технологічно дадуть змогу вилучати 3 експлуатації старі та неефективні елементи і механізми газотранспортної системи.

Практичне підключення приватного інноваційно-інвестиційного капіталу для вимог газорозподільних підприємств може виконуватися і через систему державно-приватного партнерства (ДПП), для чого в Україні існують відповідні нормативно-правові передумови, що опираються на ряд законодавчих актів. Реалізація рекомендованого підходу потребуватиме і перегляду існуючих методів до визначення тарифів на послуги з транспортування, зберігання та розподілу природного газу. Так, з наміром забезпечення окупності та ефективності інноваційно-інвестиційних проектів рекомендується механізм фінансового забезпечення інтересів приватних інвесторів, в основі якої лежить процес розподілу тарифної виручки між приватними інвесторами та газорозподільними підприємствами пропорційно до обсягів вартості інвестованого капіталу.

Отже, імплементація організаційно-інноваційних змін у діяльність газорозподільних підприємств, посилює свій реальний зміст за умов включення приватного інноваційноінвестиційного капіталу. Задля ліквідації ризиків і загроз, які можуть бути пов'язані із потенційною можливістю наявного конфлікту між приватним та державним інвестиційним капіталом, між державними та приватними суб'єктами господарювання ми можемо запропонувати включити до складу організаційно-економічного механізму управління інноваційно-інвестиційними процесами газорозподільних підприємств певні елементи, що систематизовані єдиним механізмом залучення приватного, а також іноземного капіталу [7]:

1) передача зазначених комплексів у приватну власність або довгострокову оренду; 2) узгодження механізму ціноутворення в межах виробничо-технологічних комплексів на основі дезінтеграції тарифів на розподіл, шляхом формування відокремлених структурних складових тарифів за 
окремими стадіями технологічних процесів з виділенням тарифів на подачу та передачу по газу лінійною частиною; 3) залучення на конкурсній основі приватних інвесторів до реалізації інноваційно-інвестиційних проектів в межах зазначених дискретних виробничо-технологічних комплексів; 4) централізоване визначення пріоритетних об'єктів інвестування в межах всієї ГТС; 5) формування дискретних виробничо-технологічних комплексів у межах діючих газорозподільних підприємств 3 отриманням в подальшому такими комплексами статусу самостійних або частково самостійних господарюючих суб'єктів; 6) забезпечення жорсткого державного та регіонального контролю за реалізацією інноваційно-інвестиційних проектів на всіх стадіях; 7) забезпечення централізованого державного контролю за діяльністю всіх суб'єктів господарювання, що входять до складу ГТС, централізоване державне управління та координація їх операційної діяльності 3 транспортування газу існуючим Об’єднаним диспетчерським управлінням «Укртрансгазу» та «Укргазу».

Передумовами формування ефективного механізму управління інноваційно-інвестиційною активністю на газорозподільних підприємствах є запропоновані нами теоретичні положення та практичні рекомендації щодо: 1) діючих інновацій (інноваційних бізнес-процесів); 2) дуальності приватного інноваційно-інвестиційного капіталу; 3 ) гнучкості тарифу розподілу газу.

Концепція діючих інновацій передбачає широке використання нововведень, які охоплюють весь спектр бізнес-процесів підприємства, пріоритетом яких є удосконалення діяльності 3 метою вибору вектору орієнтації на споживачів газових послуг, і які спрямовані на досягнення синергетичного ефекту підприємства за рахунок впливу росту ефективності всіх його функціональних одиниць. Концепція грунтується на використанні дієвого та стадійного підходу, сутність якого у даному випадку полягає у комплексному розгляді взаємопов'язаних і взаємодіючих бізнес-процесів, об'єднаних у мережу, яка охоплює всі основні функції, що виконуються в підрозділах підприємства (рис. 1). Таким чином, сутність дієвого та стадійного підходу, до управління полягає у формуванні множини бізнес-процесів, як сукупності видів діяльності підприємства 3 подальшим управлінням цими процесами [8].
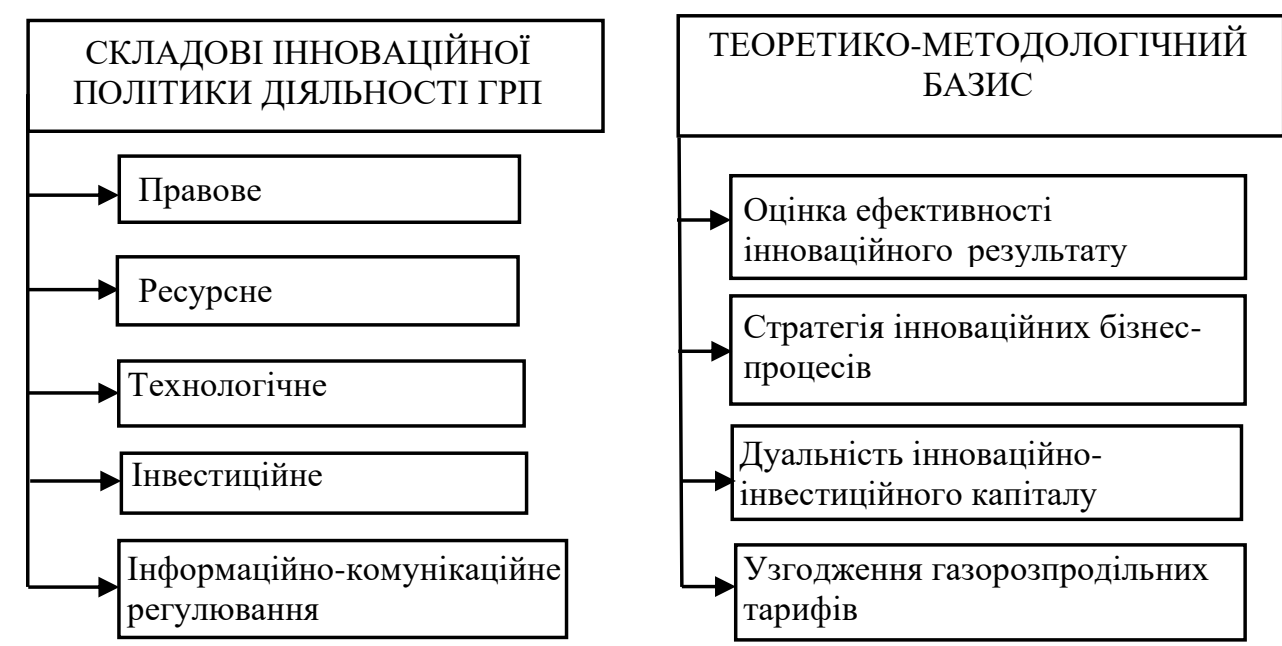

Рис.1. Передумови формування інноваційної політики на ГРП за стадійними підходами Джерело: Власна розробка автора

Враховуючи, що реалізований дієвий підхід пов'язаний із виникненням синергетичних зав'язків між процесами, то дієві інновації пропонується розглядати в рамках комбінованого процесносинергетичного підходу, виділяючи такі їх види: 1) дієві інновації мікро-рівня: організаційні, збутові, кадрові, інформаційні, фінансові, безпечні; 2) процесні інновації макро-рівня: правові (регламентні), організаційно-економічні, інформаційно-мережеві, зовнішні, інституційні.

Системність дієвості та стадійності інноваційно-інвестиційної активності відтворення діяльності ГРП спричинило розгляд візуалізованої взаємоузгодженої класифікації інноваційної активності на мікро та макро рівнях (рис 2). 


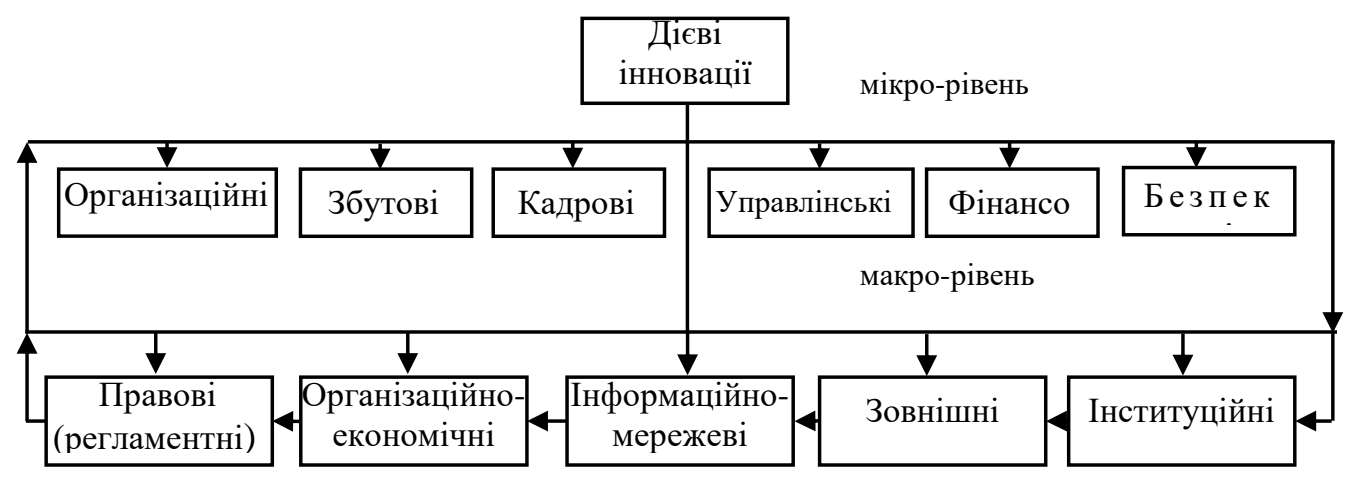

Рис. 2. Класифікаиія дієвих інновачій

Джерело: Удосконалено автором на основі [9].

Висновки та перспективи подальших досліджень. Передумови формування інноваційної політики дозволяють стверджувати про синергетичний ланцюговий ефект між складовими інноваційної політики та теоретико-методологічного базису.

Дуальність інноваційно-інвестиційного капіталу на газорозподільних підприємствах передбачає створення комплексу як внутрішніх (на рівні підприємства), так і зовнішніх умов для залучення такого капіталу з метою вирішення завдань інноваційного розвитку шляхом часткової (точкової, вибіркової) приватизації існуючих газорозподільних потужностей в межах діючих підприємств, які потребують капітального ремонту, модернізації, технічного переоснащення, а також створення нових об'єктів логістичного та розподільного використання.

Зміни у зовнішньому правовому полі, а також зміни у механізмі управління інноваційноінвестиційними процесами на рівні газорозподільних підприємств, дали б можливість для існування окремих виробничих об'єктів та технологічних комплексів, що знаходяться у приватній власності, які в принципі відповідають світовій практиці та росту процесів формування газотранспортних потужностей у різних державах світу з поступовою зміною форм власності та підпорядкуванню цих процесів домінанті економічної доцільності та ефективності залежно від етапності розвитку національних газових ринків.

Практична реалізація підходу щодо уніфікації тарифів з розподілу, який дозволяє виділяти окремі структурні складові тарифів з прив'язкою їх до окремих виробничо-комерційних процесів чи частин таких процесів, дозволяє сформувати механізм розподілу загальної тарифної виручки, отриманої газорозподільними підприємствами чи оператором газотранспортної системи, між суб'єктами господарювання пропорційно до обсягів наданих ними послуг чи окремих складових цих послуг або ж на інших засадах, що не суперечать чинному законодавству. При цьому, даний підхід повністю інтегрується з більшістю відомих методик розрахунку тарифів, що застосовуються у європейській та світовій практиці. Те ж саме стосується і методики, яка застосовується в Україні при розрахунку тарифної виручки від надання послуг з постачання природного газу.

Отже, результат проведеного аналізу інноваційних напрямів, дозволить імплементувати концепцію дієвих інновацій, концепцію дуальності приватного інвестиційно-інноваційного ресурсу та підходи щодо уніфікації тарифів по газорозподілу, в діяльність газорозподільних підприємств 3 метою подолання сформованих негативних тенденцій.

\section{Джерела та література}

1. Лінчевська Н. М. Формування організаційно-економічного механізму управління інноваційноінвестиційними процесами на газотранспортних підприємствах : автореф. дис. канд. екон. наук : 08.00.04. / Н. М. Лінчевська. - Івано-Франківськ : Івано-Франківський національний технічний університет нафти і газу, 2015. - $301 \mathrm{c}$.

2. Петренко В.П., Кісь С. Я., Швидкий Е. А. Управління діяльності підприємств нафтогазового комплексу на засадах інтелектуалізації та інтелектокористування: монографія. Івано-Франківськ, 2013. 278 с. 
3. Дзьоба О. Г., Лінчевська Н. М. Нові підходи до залучення інноваційно-інвестиційного капіталу в об'єкти газотранспортної інфраструктури. Формування ринкових відносин в Україні: збірник наукових праць. 2014. Вип. 7 (158). С. $24-29$.

4. Відомості Верховної Ради України: Закон України "Про трубопровідний транспорт" від 15 травня 1996 року. №192/96-BP. URL:https://zakon.rada.gov.ua/laws/show/192/96-вр.

5. Энергоавантюры ЕС на Украине: приватизация ГТС, передел доходов от транзита и виртуальный реверс. URL: www.regnum.ru/news/polit/1781733.html.

6. Дзьоба, О. Г. Організація і планування виробничо-комерційної діяльності підприємств транспорту і зберігання нафти і газу : навч. посіб. Івано-Франківськ : ІФНТУНГ, 2011. 466 с.

7. Діяк І. В., Осінчук 3.П., Карп І.М. Газова галузь України. Становлення, досягнення, особистості. Монографія: Івано-Франківськ : Лілея-НВ, 2000. 231 с.

8. Якимів В. І., Касинець О. О., Галазюк Н. М. Теоретико-методологічні аспекти регулювання діяльності природних монополій. Науковий вісник НЛТУ України. 2010. Вип.20.8. С. 265-269.

9. Сидорова А.В., Курносова О.А. Процессные инновации в системе управления развитием предприятий. Економіст. 2008.№1.С. 28-32.

\section{References}

1. Linchevs'ka N. M. (2015) Formuvannya orhanizatsiyno-ekonomichnoho mekhanizmu upravlinnya innovatsiyno-investytsiynymy protsesamy na hazotransportnykh pidpryyemstvakh [Formation of organizational and economic mechanism of management of innovation and investment processes in gas transportation enterprises]. IvanoFrankivs'k [in Ukrainian].

2. Petrenko V. P., Kis' S. YA., Shvydkyy E. A. (2013) Upravlinnya diyal'nosti pidpryyemstv naftohazovoho kompleksu na zasadakh intelektualizatsiyi ta intelektokorystuvannya [Management of Oil and Gas Complex Enterprises on the Basis of Intellectualization and Intellectual]. Ivano-Frankivsk [in Ukrainian].

3. Dz'oba O. H. \& Linchevs'ka N. M. (2014) Novi pidkhody do zaluchennya innovatsiyno-investytsiynoho kapitalu v ob"yekty hazotransportnoyi infrastruktury [ New approaches to attracting innovative investment capital in the objects of gas transport infrastructure]. Formuvannya rynkovykh vidnosyn v Ukrayini- Formation of market relations in Ukraine: a collection of scientific works. 7 (158), 24-29. [in Ukrainian].

4. Zakon Ukrainy "Pro truboprovidnyy transport" pryiniatyi 15 travnya 1996 roku. №192/96-VR. [Law of Ukraine "On Pipeline Transport" of May 15, 1996. №192/96-BP]. Retrieved from https:

//zakon.rada.gov.ua/laws/show/192/96vr]. [in Ukrainian].

5. Energoavantyury YES na Ukraine: privatizatsiya GTS, peredel dokhodov ot tranzita i virtual'nyy revers [EU energy ventures in Ukraine: privatization of gas transportation systems, redistribution of transit revenues and virtual reverse]. Retrieved from www.regnum.ru/news/polit/1781733.html [in Russian].

6. Dz'oba, O. H. (2011) Orhanizatsiya i planuvannya vyrobnycho-komertsiynoyi diyal'nosti pidpryyemstv transportu i zberihannya nafty i hazu [ Organization and planning of production and commercial activity of oil and gas transport and storage enterprises]. Ivano-Frankivs'k, 466 [in Ukrainian].

7. Diyak I. V. \& Osinchuk Z.P. \& Karp I.M. (2000) Hazova haluz' Ukrayiny [Gas industry in Ukraine]. Stanovlennya, dosyahnennya, osobystosti-Becoming, achieving, personality. Monograph: Ivano-Frankivsk: Lilya-NV [in Ukrainian].

8. Yakymiv V.I., Kasynets' O.O., Halazyuk N.M. (2010) Teoretyko-metodolohichni aspekty rehulyuvannya diyal'nosti pryrodnykh monopoliy [Theoretical and methodological aspects of regulating the activity of natural monopolies]. Naukovyy visnyk NLTU Ukrayiny-Scientific Bulletin of NLTU of Ukraine. 20 (8), 265-269. [in Ukrainian].

9. Sidorova AV, Kurnosova O.A. (2008) Protsessnyye innovatsii v sisteme upravleniya razvitiyem predpriyatiy [Process innovations in the enterprise development management system]. 1, 28-32. [in Russian]. 